\title{
KÜRESELLEŞME SÜRECINDE MUHASEBE UYGULAMALARI KONUSUNDA YAPILAN ÇALIŞMALARA GENEL BİR BAKIŞ
}

\author{
A GENERAL OVERVIEW OF WORK IN ACCOUNTING APPLICATIONS \\ DURING GLOBALIZATION
}

\section{Öz}

Bu çalışmanın amacı, küreselleşme sürecinde muhasebe uygulamalarını incelemektir. Bu amaçla, bu konuda daha önce yapllan çalışmalar uluslararası muhasebe standartları çerçevesinde incelenecek ve muhasebe uygulamaları hakkında genel bir değerlendirme yapılacaktır. Sonuç olarak, küresel muhasebe iklimini yönlendiren temel kuruluşun IFAC ve IASC Vakfi olduğu görülmüştür ve dünya çapında şirketlerin kullanacağı ortak bir muhasebe sisteminin oluşturulması amacıyla 1973 yılında IASB (International Accounting Standards Board) kurulmuş ve Uluslararası Muhasebe Standartları (UMS), Uluslararası Finansal raporlama Standartları (UFRS) adı altında uluslararası alanda kabul gören muhasebe standartları oluşturulmuş ve Türkiye'de de Türkiye Muhasebe Standartları (TMS) ve Türkiye Finansal Raporlama Standartları (TFRS) olarak kabul edilen standartlar ortaya çıkmıştır.

Anahtar Sözcükler: Muhasebe uygulamaları, küreselleşme süreci, uluslararası muhasebe standartları.

\begin{abstract}
The aim of the study is to examine accounting practices in the process of globalization. For this purpose, previous work on this subject will be examined within the framework of international accounting standards and a general evaluation will be made about accounting practices. As a result, IFAC and the IASC Foundation are the main institutions driving the global accounting climate, and IASB (International Accounting Standards Board) was established in 1973 to create a common accounting system for companies worldwide. Internationally accepted accounting standards have been established under the name of the field and also Turkey Accounting Standards (TAS) and Turkey Financial Reporting standards (IFRS) has emerged as accepted standards in Turkey.
\end{abstract}

Keywords: Accounting applications, globalization process, international accounting standards.

\footnotetext{
*Prof. Dr., Kahramanmaraş Sütçü İmam Üniversitesi, İ̈BF, İşletme Bölümü, mahmutyardimcioglu@gmail.com ORCID: 0000-0002-1335-8357

**Öğr. Gör., Osmaniye Korkut Ata Üniversitesi, Düziçi Meslek Yüksekokulu, aliyoruk1517@gmail.com ORCID: 0000-0001-5390-2137
} 


\section{GIiRiş}

Günümüz küreselleşen dünya ekonomisinde ulusal düzeyde faaliyet gösteren işletmeler, ulaştırma ve iletişim alanındaki gelişmelerle birlikte teknolojik ve sosyal değişmelerden faydalanmak amacıyla hızlı bir şekilde farklı ülkelere açılmaya ve yeni yatırım platformlar bulmaya çalışmaktadırlar (Şahin ve Pazarçeviren, 2007:131). Elbette ki böylesi bir durum da 2000'li yılların dünyası 1950'li yılların dünyasına kıyasla oldukça farklı uygulamaları içermektedir. Bu 50 yıllık dönem içerisinde yapılan uluslararası anlaşmalar ile ülkeler siyasi sınırlarını muhafaza ederken, ekonomik sınırların ortadan kalkmasıyla küreselleşme süreci başlamıştır. Bu küreselleşme süreci dünyada tek bir ortak pazar olgusu oluşturmuş ve aynı zamanda uluslararası mal ve sermaye hareketlerini de büyük bir hızla artırmıştır. Ortaya çıkan bu farklılaşma, muhasebe uygulamalarında da değişmeyi ve dönüşmeyi mecburi kılmış, muhasebe dilinin ayrı ayrı ülkede farklı bir muhasebe dili yerine dünya genelinde ortak bir dilin uygulanması gerektiği fikrini doğurmuştur.

Muhasebe alanında dünya üzerinde uzun süreli çalışmalar yapılarak; muhasebe uygulamalarında ve muhasebe raporlamalarında anlamlı ve gerçekçi bilgiler sunulması temel hedeftir. Gelişmiş ülkeler ortaya koydukları ulusal muhasebe standartları, kurul ya da komitelerin oluşturduğu standartlarla bu amaca çalışmışlardır. Farklı ülkelerin muhasebe standartları arasındaki farklılıklar elde edilen finansal bilgilerin mukayese edilebilmesini güç kılmakta, uluslararası şirketlerin alım satım ve birleşmeleri hususunda zorluklarla karşılaşılmasına sebep olmakta ve sermaye piyasasında fon toplama aşamasında handikap oluşturmaktadır (Korkmaz vd., 2007:96). Dünyada ki gelişmeler ekseninde birçok bilimsel sistemdekine benzer biçimde muhasebe sistemi de değişim göstermekte veyahut en azından dünya şartları bu dönüşümü empoze etmektedir. Dünyada var olan gelişmeler doğrultusunda, muhasebe sisteminin bir parçasını oluşturan hesap planlarının da uyumlaştırılması gerekir (Güneş, 2008:3).

Zaman içinde hemen hemen her konuda küreselleşme hareketlerinin tesiriyle ortak gayeye hizmet etmek maksadıyla standartlaşma oluşturulmaya çalışılmıştır. Standart ifadesi; amaca uygunluk derecesi anlamına da gelebilir ya da olması gereken anlamına da gelebilir. Para ve sermaye hareketlerinin, uluslararası ticaretin çok ehemmiyetli boyutlara ulaşması nedeniyle benzerlik içeren olayların benzer şekilde kullanılması; anlamlı, güvenilir, hakikate uygun mukayese edilebilir bilgilerin ortaya koyulması, işletmeyle alakalı bilgilerin tarafların gereksinimlerini en iyi biçimde giderilebilmesi maksadiyla muhasebe platformunda, finansal raporların hazırlanması, teori ve uygulamalar açısından uluslararası muhasebe standartlarının hazırlanması lüzumunu doğurmuştur. Hazırlanacak yüksek kaliteli standartlarla muhasebe riskini yok ederek daha fazla ticaret, yatırım ve büyümenin yapılabilmesine olanak yaratmak amaçlanmıştır (Kocamaz, 2012:106). Uluslararası muhasebe standartları, finansal raporların ve tabloların temsil ettikleri organizasyonun varlıklarının ve kaynaklarının en şeffaf ve doğru bir biçimde aksettirmesi temeline dayanmaktadır.

Çalışmanın ilk bölümünde, küreselleşme sürecine yer verilmiş ve ikinci bölümde uluslararası muhasebe standartları çerçevesinde muhasebe uygulamalarına yönelik etkileri araştırılmıştır.

\section{KAVRAMSAL ÇERÇEVE}

Güncel olarak sosyal bilimler literatüründe sıklıkla kullanılan, lakin belirsizliklerin fazla olduğu küreselleşme kavramı, kesin bir ifade biçimiyle tanımlanamamıştır. Yaklaşık 400 yıldan fazla zamandan beri küresel kavramının bir tarihi olmasına rağmen küreselleşme kavramı 1960'larda yaygın bir biçimde kullanılmaya başlanmış olup, 1980'li yıllardan beri de kullanımı artmıştır (İçli, 2001:163). Küreselleşme hususunda farklı tanımlar söz konusudur. Farklı tanımların oluşmasının temel sebebi ise, henüz bilim adamlarının küreselleşme kavramı hususunda ortak bir yargıya ulaşamamış olmalarıdır (Tağraf, 2002:35). 
Küreselleşme denildiği zaman, ana tema olarak bazıları ekonomik, bazıları sosyal, kültürel veya siyasi alanı alabilmektedir. Benzer bir durumda tanımlarda ve tariflerde, kimi zaman nedenler ve süreçler kimi zaman da sonuçlar ön planda olabilmektedir (Karakaya, 2010:3).

Kavramsal olarak küreselleşme; farklı biçimlerde algılanabilmekte ve farklı şekillerde tanımlanabilmektedir. Küreselleşme terimi; uluslararasında, sınırsız ticaret ve finansal akışlar sayesinde, teknoloji ve bilginin etkileşimi olarak ifade edilmektedir (Goyal, 2006:166).

Kimileri küreselleşmenin dünyada refahı yükselteceğini belirtirken, bununla birlikte gelişmiş ülkeler ve gelişmekte olan ülkeler arasında oluşan farkları azaltacağını belirtir, kimileri de sömürgeciliğin modern yaklaşımı olarak küreselleşme kavramını tanımlamışlardır. Küreselleşme kavramıyla alakalı olumlu yaklaşımlar söz konusu iken, bu kavramı ve süreci çok şiddetli bir biçimde eleştiren olumsuz yaklaşımlar da mevcuttur. Ayrıca küreselleşme kavramına ve küreselleşme sürecine tarafsız yaklaşan görüşler de bulunmaktadır (Kürkçü, 2013:1).

Küreselleşme kavramıyla yapılan bir diğer tanımda da; toplumların siyasal yönetimi ve yönetim politikaları, kültürleri ve ideolojisi hususunda uluslararası sermayenin ekonomi politikası, kültürü ve ideolojisinin egemenliğini kurması ve geliştirmesi belirtilmektedir (Gezgin, 2005:10).

Ekonomik küreselleşme kavramı ise bölgesel ölçeklerin ilerisinde ekonomik kuralların küresel ölçekte olması şeklinde ifade edilmektedir. Diğer bir deyişle, ülkeler arasındaki ekonomik sınırların yok olduğu, ulus devletlerin himayesindeki ulusal pazarların, küresel sermayenin himayesindeki küresel pazarlara dönüştürülmesi olarak tanımlanmaktadır (Karakaya, 2010:4).

Ekonomi alanında da birçok alandaki gibi globalleşme süreci başlamış bu globalleşme süreci ekonomik sınırları tamamıyla ülkeler arasında yok etmiştir. Ekonomi kapsamında oluşan bu küreselleşme süreci, ülkelerin ekonomilerini birbirlerine bağımlı kılmaktadır. Hem ulusal hem de uluslararası açıdan finansal bilgilerin, küreselleşmeyle birlikte entegre olması zaruridir (Şahin ve Pazarçeviren, 2007:130).

Küreselleşme sürecinin ortaya çıkardığı yeni durumun kökeninde, işletmelerin dünyanın her bölgesinde herhangi bir sinırlamaya zorlanmadan tek bir pazar gibi faaliyet gösterebilmesi gayesi vardır. Dünyanın her yerinde tek bir pazar olabilmek gayesiyle ülke yönetimlerinin, ülke gümrüklerini daha naif bir yapıya dönüştürmeleri amaçlanır. Bu çerçevede gelişmiş ülkeler tarafından yönlendirilen Dünya Ticaret Örgütü’nün oluşturduğu uluslararası ticaretteki yeni düzenlemeler empoze edilmektedir (Tağraf, 2002:34).

Ülkeler arasındaki muhasebe uygulamalarında farklılıklar, finansal bilgilerin karşılaştııılmasını zorlaştırmakta, uluslararası işletmelerin faaliyetlerini sınırlamakta ve sermaye piyasalarının gelişimini engellemektedir (Kalmış ve Dereköy, 2010: 124). Bu husus, yatırımcı açısından bazı riskleri de beraberinde ortaya çıkarmaktadır. Yatırım yapılacak ülkedeki muhasebe uygulamalarının yeterince anlaşılamaması; bu risklerden en ehemmiyetlisidir (Şahin ve Pazarçeviren, 2007:131).

Muhasebe uygulamaları küresel işletmelerin ve de diğer işletmelerin hem gelişmelerini hem de sürekliliklerini devam ettirme konusunda önemli bir görev almıştır. Uluslararası ticaret hacminin artmasıyla beraber her ülkede farklı olan muhasebe uygulamalarının uyumlaştırılmasını zaruri yapmış, 1972 yılında uluslararası muhasebe standartlarının temeli atılmıştır (Güneş vd., 2012:62).

Muhasebe standartları kavramı muhasebe açısından ele alındığında, muhasebe uygulamalarının çerçevesini oluşturan kurallar bütünü olarak ifade edildiği görülmüştür (Atmaca, 2010:5).

Finansal tabloların tek düzen olarak ortak bir dille hazırlanmasına ve daha güvenilir olmasına, muhasebe standartlarının oluşturulması imkân sağlamaktadır. Bilakis, finansal sistemin etkili bir biçimde çalışabilmesi maksadıyla muhasebe standartlarının oluşturulmasıyla birlikte kaliteli de oluşması gerekmektedir. Kaliteli muhasebe standartları belirli kavramsal düzen içinde açık ve anlaşıır olmaları, finansal bilgi kullanıcılarına tam olarak cevap verebilmeleri, birbiri ile tutarlı olmaları, muhasebenin konusunu içeren işlemlerin karşılaş̧ıırılabilirlik ve tutarlılığın oluşturulmasını 
teminen alternatif uygulamalardan kaçınmaları gibi ana özellikleri içermelidir. Küreselleşen dünyada muhasebe standartlarına duyulan gereksinim, uluslararası sermaye hareketlerinin çoğalmasından kaynaklanmaktadır. Muhasebe standartlarının kaliteli olmakla beraber, uluslararası muhasebe standartlarıyla da entegre olması lazım gelir (Bağc1, 2002:25-26).

Muhasebe standartlarının oluşturulma amaçları şu şekilde sıralanabilmektedir (Kiracı ve Köse, 2002:49):

- Pratikteki farklı durumları yok ederek, muhasebe ilkelerinde tekdüzeni oluşturmak,

- Finansal tabloların açık ve uygun, hatta anlaşılabilir, tarafsız ve mukayese edilebilir olmasını sağlamak,

- İşletme ile ilgili kişi ve kurumların yanlış değerlendirmelerine ve karar vermelerine mani olmak,

- Uluslararası alanda finansal bilginin üretimi ve sunulması esnasında ortak bir lisan oluşturmak,

- Çokuluslu işletmelerin yüzleştikleri farklı muhasebe standartlarından kaynaklanan problemleri çözümlemektir.

Gelişen ülkelerin liderliğinde ve gelişmekte olan ülkelerin de müdahil olmasıyla, 1973’te Uluslararası Muhasebe Standartları Komitesi (IASC) kurulup, faaliyete başlamış ve Uluslararası Muhasebe Standartları (IAS) iyileştirilip yayınlanmıştır. Bu uluslararası standartların ülkeler konjektüründe, yeni geliştirilecek ulusal muhasebe standartlarında baz alınması öngörülmüştür (Korkmaz vd., 2007:97).

IASC’nin gayesi dünyada tek tip muhasebe standartları yapmak ve de uygulama sahasını geliştirmektir. Ayrıca, çoklu muhasebe standartlarının farklılığı sorunu çözülmez gibi görünmesi sebebiyle yönetim kurulu işe, bütün ülkeler açısından onaylanabilecek uluslararası muhasebe standartlarının oluşturulmasını başlangıç seçmişlerdir. Lakin bu etap bir hayli zor, hemen hemen imkânsız gibi görünmekteydi (Aysan, 2008:47).

Komitenin esas gayesi, uluslararası muhasebe standartlarının üretimini yaygınlaştırıp ve kullanımını da artırarak, muhasebe mesleğinin uluslararası sahada sağlıklı bilgiler üreten bir oluşuma erişmesini sağlamak olarak belirlenmiştir. Komite bu görevlerini yerine getirirken, taslakları hazırlamış, mesleki örgütlerin görüşlerini alarak bunları meslek mensuplarına önermiştir. Komite, bu konudaki çalışmaları yürütürken, görüş ve önerileri, sunulan çeşitlilikleri bir araya getirerek standartlara son şekillerinin verilmesi ve yayınlaması görevlerini de üstlenmiştir. UMS-1 ve UMS-2 standartları 1975 yılında bu şekilde yayınlanmıştır (Güvemli, 2008:5).

Münih’te 1977 y1lında gerçekleştirilen 11. Dünya Muhasebeciler Kongresi’nde, Uluslararası Muhasebeciler Federasyonu (IFAC) kurulmuştur. IFAC'1n kurulması ile çalışmalar süreklilik kazanmış ve yüzden fazla ülkenin meslek örgütlerinin desteği sağlanmıştır. Uluslararası Muhasebe Standartları Komitesi de 1980'li yıllarda genişleme sürecine girmiş ve IFAC ile çalışmaya başlamıştır. Muhasebeciler Federasyonu'nun bütün katılımcıları bu Komite'nin üyelerine dönüşmüş ve IFAC, Komite'yi uluslararası standart koyucusu olarak kabul etmiştir (Bekçi ve Özdemir, 2006:145).

Avrupa Muhasebeciler Federasyonuyla (FEE) 1989 yılında yapılan gerçekleştirilen görüşmeler neticesinde, Avrupa Muhasebeciler Federasyon'un uluslararası uyumlaşmaya destek vermesine ve IASC'a daha fazla katkı yapmasına karar verilmiştir. Lakin Amerikan mesleki otoritesinin (USAGAAP) yerini UMS' lere devretmeyi kabul etmemesi çok ehemmiyetli bir gelişme olarak görülmüştür ve bu durumun küresel bazda uluslararası muhasebe standartlarının kabulünü sağlamada önemli bir adım olduğu ifade edilmiştir (Aysan, 2008:47). 
Bu arada belirtmek gerekir ki, yukarıda sözü edilen Avrupa Muhasebe Uzmanları Federasyonu ile IASC aynı doğrultuda çalışan kurumlardır. Her ikisi de küresel muhasebe standartlarının uyumlaştııılması amacını taşımaktadırlar. Her ikisi de, finansal raporlama maksadıyla kullanılan kalitesi yüksek, şeffaf ve mukayeseli bilgiye imkân veren tekdüzen, anlaşılır, küresel muhasebe standartlarını oluşturmaya çalışan kurumlardır (Güvemli, 2008:6).

Muhasebe uygulamalarında ortak dil ve terim birliği sağlamak maksadıyla 1973 yılı ile 2000 yılına kadar Uluslararası Muhasebe Standartları Komitesi (International Accounting Standards Committee - IASC) eliyle çıkarılan ve bazıları uygulamadan kaldırılan 41 adet, UMS (Uluslararası Muhasebe Standartları) yayınlanmıştır. İlerleyen zamanda bu kuruluşun devamı olarak kurulan IASB'nin (Uluslararası Muhasebe Standartları Kurulu) çıkardığı 7 standart ise, UFRS (Uluslararası Finansal Raporlama Standartları) olarak kabul edilmiştir (Toraman ve Bayramoğlu, 2006:465).

IASC 24 Mayıs 2000'de vakıf niteliğine evrildi. O günden beri IASC Vakfı (IASC Foundation) adıyla kabul edilmektedir (Güvemli, 2008: 5). 2002'de Avrupa Birliği bünyesindeki ülkelerin, menkul kıymet borsalarında bulunan firmaların Ocak 2005'den bu yana UFRS'leri uygulamalarının bir mecburiyet olduğunu deklare etti. Bu şunu ifade ediyordu; 2005 yılından bu yana 8000 Avrupa firması finansal raporlarını UFRS'ye uyumlu bir şekilde düzenlemek mecburiyetindeydiler (Aysan, 2008:48).

1973 yılından bu yana Dünya’da ortaya konulan küresel muhasebe standartları arayış çabası ülkemize 1994 yılında yansımıştır ve Türkiye Serbest Muhasebeci Mali Müşavirler ve Yeminli Mali Müşavirler Odaları Birliği’ nin (TÜRMOB) desteğiyle beraber Türkiye Muhasebe ve Denetim Standartları Kurulu (TMUDESK) kurulmuştur (Karakaya, 2010:87).

Türkiye’de, birçok kurum muhasebe standartlarıyla ilgilenmiştir. Bunlar; Maliye Bakanlığı, Türk Standartları Enstitüsü, Türkiye Muhasebe ve Denetim Standartları Kurulu, Sermaye Piyasası Kurulu, Sigorta Murakabe Kurulu, Türkiye Bankalar Birliği Kurullarıdır. Bu kurullar, yaptıkları çeşitli çalışmalarla, ülkemizde muhasebe standartları kültürünün yerleşmesi konusunda önemli hizmetler sunmuşlardır. Ancak, muhasebe standartlarıyla bu kadar fazla kurumun alakadar olması, karmaşaya sebebiyet doğurmuştur. Bu amaç doğrultusunda ülke bütününde muhasebe standardı yayınlamak maksadıyla, Türkiye Muhasebe Standartları Kurulu 2002 yılında kurulmuştur (Erdoğan ve Dinç, 2009:156).

TMSK (Türkiye Muhasebe Standartları Kurulu) UFRS'lerin tamamını Türkçeye çevirdi ve TFRS’ye (Türk Finansal Raporlama Standartları) dönüştürüp açıkladı. 2008 yılının ortalarından bu yana UFRS'lere entegre çalışmaları sonuçlandı. Günümüz de ise, Türkiye'de bulunan firmalar UFRS'lere çok da uzak olmayan SPK standartlarından faydalanmaktadır. Lakin TMSK'ya Tek Düzen Muhasebe Standartlarının gözlemlenip, uygulanması ve yorumlanması hususunda tek otorite olarak yetki verilmesi neticesinde, Merkez Bankası ve Maliye Bakanlığı UFRS'lere göre yapılanmak mecburiyetinde kald1 (Aysan, 2008:48).

Küreselleşme konusu ve Avrupa Birliğine üyelik süreci ile alakalı çalışmalar Türkiye açısından ulusal muhasebe standartlarının UMS/UFRS ile entegre bir şekilde hazırlanmasını önemli hale getirmiştir. İlk etap da 1994 yılında oluşturulan Türkiye Muhasebe ve Denetim Standartları Kurulu UMS/UFRS ile entegre standartlar oluşturmak maksadıyla çeşitli çalışmalar icra etmiştir. Türkiye'de ulusal muhasebe standardı yayınlama hususunda 1999 yılında TMSK kurulmuştur ve 39 adet TMS, 6 adet TFRS ve iki adet TMS taslağını 1162 sayfadan oluşan bir kitap olarak yayınlamıştır. Lakin 02.11.2011 tarihli ve 28103 sayılı Resmi Gazate'de neşredilen 660 sayılı Kanun Hükmünde Kararnameyle (KHK) TMSK yerini KGK'ya bırakmış ve TMS/TFRS yayımlama yetkisi bu kuruma verilmiştir (Toroslu, 2014:29; Ürgüp, 2016:10).

KGK (Kamu Gözetimi Kurulu) tarafından yayımlanmış olan muhasebe standartlarıyla bir taraftan kavram birlikteliği sağlanmış diğer taraftan ülkemizde uygulanan muhasebenin evrensel bir dil niteliğine sahip olması sürecinde çok önem arz eden bir adım atılmıştır. Bu düzenlemeyle birlikte 
işletmeler, KGK tarafından yayımlanmış olan TMS'leri uygulayacaklardır (Toroslu, 2014:57; Ürgüp, 2016:22).

Muhasebe standartlarının uygulanması açısından ülkemizdeki uygulamaya bakıldığında aşağıdaki durum saptaması yapılabilir (Akdoğan, 2007:108):

- TFRS (IFRS) bazlı konsolide finansal tablolar borsaya kayıtlı işletmeler tarafından hazırlanmaya başlamış, 2004 yılından bu yana bazı firmalarda konsolide tabloların düzenlenmesinde bu uygulama nispeten yapılmıştır.

- TMS standartlarına uyulacağını BDDK yayımladığı yönetmeliklerle deklare etmiştir. Bankalar TMS/TFRS bazlı konsolide tablo oluşturmaya başlamışlardır.

- İkili uygulama şu anda da devam etmektedir. Borsada yayımlananlar TMS/TFRS esasları dikkate alınarak hazırlanır iken, yasal tablolar şu anda eski uygulamalara (Tekdüzene ve Vergi Kanunlarına) temel alınarak hazırlanmaktadır.

- Konsolide tablolar TMS bazlı hazırlanırken bireysel(şahsi) bilançolar şu anda eski uygulamaya temel alarak hazırlanmaktadır. Borsaya kayıtlı bulunmayan işletmeler hala TMS esaslarını uygulamamaktadır.

Muhasebe standartlarında uluslararası uyumun gerçekleştirilmesi ve ülke genelinde muteber olacak uluslararası standartların düzenlenmesi maksadıyla; Ekonomik İşbirliği ve Kalkınma Teşkilatı, Birleşmiş Milletler, Uluslararası Muhasebe Standartları Kurulu, Avrupa Birliği ve Uluslararası Sermaye Piyasası Kurulları Örgütü aracılığıyla çalışmalar düzenlenmektedir. Avrupa Birliğine giriş süreci devam eden ülkemizde de, hem Avrupa Birliği hem de küresel düzeyde uluslararası sistemle birliktelik ve uluslararası sermaye piyasalarında bulunabilmek maksadıyla ulusal muhasebe ve denetim standartlarının uluslararası entegrasyonunun sağlanması büyük önem arz etmektedir (Parlakkaya, 2004:120).

\section{SONUÇ VE DEĞERLENDİRME}

Küreselleşme ile birlikte, son çeyrek yüzyılda, dünyada işletmeler içinde tek bir dil kullanılmaya başlanmış ve muhasebe uygulamaları da ticari işlemlerde ki gelişmelere paralel bir biçimde ilerlemiştir (Güneş vd., 2008:64).

Ekonomik ve teknolojik gelişmelerin neticesinde dünyada görülen küreselleşme trendi, coğrafi sınırları yok ederek birçok değerin uluslararası bölüşümünü sağlamıştır. Küreselleşme mali platformda, çok uluslu şirketlerin doğmasına, uluslararası para ve uluslararası denetim firmalarının kurulmasına, sermaye piyasalarının gelişme göstermesine, yabancı sermaye iştiraklerinin artmasına ve muhasebe denetim standartlarının ulus sınırlarının aşmasına sebep teşkil etmiştir. Farklı ülkelerin mali tablolarının karşılaştırılabilmesi, uluslararası yatırımcılara doğru ve güvenilir bilgiler sağlaması sadece muhasebede uluslararası standartlara entegre olabilmesiye mümkündür (Parlakkaya, 2004:136).

Sadece ulusal muhasebe uygulamaları, ekonomik ve sosyal düzendeki değişimler ekseninde gelişmekte ve değişiklik yaşamaktadır. Bu sebepten ötürü standartların ortaya koyulması ve entegre olması safhasında bütün ülkenin kendi özel koşullarının varlığı göz ardı edilmemelidir. Entegre çalışmaları, sadece uluslararası muhasebe standartları tercümesinden oluşmaması gerekir. Entegre çabası neticesinde dünya genelinde, finansal tablolar tek bir dil ve muhasebe diliyle anlatılması söz konusu olacaktır. Böylece finansal tablolar da normlara ulaşılmış olacak ve bu normların mukayese edilebilirliği, anlaşılabilirliği, konsolide edilebilirliği, güvenilirliği kazanılmış olması söz konusudur (Kiracı ve Köse, 2002:69). 
Muhasebe uygulamalarında ulusal ve uluslararası platformda birliktelik sağlamak için muhasebe standartları oluşturma faaliyetleri içine girilmiştir. Yapılan bu çalışmalar da birden fazla uluslararası kuruluş görev almıştır. Dünyada küresel hususta muhasebe ve finansal raporlama standartlarının oluşturulmasını sağlamak bu kuruluşların ortak gayesidir. Bu kuruluşların başında ise IASC (Uluslararası Muhasebe Standartları Komitesi) gelmektedir. Amac1 ise, muhasebe uygulamalarında birlik oluşturmak, muhasebeden sağlanan bilgilerin uluslararası platformda ortak bir oluşuma dönüşmesini sağlamak, kamuya deklare edilen denetlenmiş finansal tablolarda uygulanması gereken muhasebe standartlarını oluşturmak ve muhasebe standartlarının dünya genelinde benimsenmeleri için çaba göstermektir (Çelik, 2013:117).

Uluslararası standartların alınıp uygulanması, ulusal düzeyde yasal değişiklikler yapmayı gerektirmektedir. Bu değişiklikleri yapmak kolay değildir. Çünkü hesaplaşma düzeni, kurumların kendi aralarında veya kurumlarla devlet arasında ve kişilerin kendi aralarında bu hukuk çerçevesinde yürümektedir. Bir uluslararası standardın alınıp uygulanması bu hukuk düzeninde kimi değişikliklerin yapılmasını da zorunlu kılabilmektedir. Her ülkenin kendi geliştirdiği genel kabul görmüş muhasebe ilkeleri ve kuralları, bunları içeren hukuki çerçeve, yaşanılan sorunun ana kaynağını oluşturmaktadır. Her ulusun uluslararası standartlarla olan etkileşimi, yukarıda sorunların kaynağı olarak belirtilen muhasebe ilke ve kurallarıyla bunların hukuki düzenini gözden geçirmeyi gerektirmektedir. Öncelikle genel kabul görmüş kavramını, uluslararası genel kabul görmüş durumuna getirme çabası, muhasebe standartlarında birliktelik sağlanarak aşılmaya çalışılmaktadır (Güvemli, 2008: 256-257).

Türkiye, tekdüzen hesap planı açısından önemli değişimler gerçekleştirmiştir. Bu değişimlerin 1şı̆̆ında konu değerlendirildiğinde Türkiye'nin gelecek yıllarda, uluslararası standartlara entegrasyonunun başarılı olacağı varsayılabilir.

Son 60 yıl boyunca oluşan ve çalışmamızda bahsettiğimiz tarihsel gelişmeler ve gelişmeler doğrultusunda uluslararası gelişmelere göre, aşağıda ifade edilen direktifler doğrultusunda çalışarak, muhasebe mesleğini ciddi biçimde geliştirmemiz ülkemiz açısından önem arz etmektedir (Aysan, 2008:48):

1. Ülkede UFRS'lere tam olarak entegre olma konusunda ivme kazanması için tam uyumun başarılması maksadıyla meslek tarafından sağlanan desteklerin arttırılması gerekmektedir. Bu sıkı değişimin sağlanabilmesi için birçok yasal ve idari araştırmaya ihtiyaç duyulduğu görülmektedir.

2. Yüksek mesleki standartlar oluşturabilmek amacıyla, Türkiye Muhasebe Uzmanları Derneğinin toplum ve firmalar tarafından mali desteğe gereksinim bulunmaktadır. TMSK, Merkez Bankası ve diğer kurumlarla sivil toplum örgütlerinin bu gayretlerine destek olunması lazım gelir.

3. 3568 sayılı meslek kanunu bahsinde çalışmalar yapılmalı, finansal raporlama, muhasebe ve denetimle alakalı mesleki standartların geliştirilmesine yönelik IFAC ve AB standartlarına hususunda kapsamlı değişiklik içeren araştırmalara yardımcı ve destek olmak icap etmektedir.

Dünyadaki gelişmelere ülkemizde de benzer biçimde birden fazla yasal altyapı düzenlemesi gerçekleştirilmiştir. Lakin, uygulamaların yasalarla uyumlu hale dönüştürülebilmesi için çalışmaların devam ettirilmesinin lüzumlu olduğu düşünülmektedir (Güneş vd., 2008:64). 


\section{KAYNAKÇA}

Akdoğan, N. (2007). Türkiye Muhasebe/Finansal Raporlama Standartlarının Uygulanma Süreci: Sorunlar, Çözüm Önerileri. Mali Çözüm, İSMMMO Yayın Organı, (80): 101-118.

Atmaca, M. (2010). Uluslararası Finansal Raporlama Standartlarına ve Vergi Yasalarına Göre Düzenlenen Temel Mali Tabloların Finansal Analiz Açısından Karşılaştırmalı Olarak İncelenmesi ve Türkiye Uygulaması. (Yayımlanmamış Doktora Tezi). Marmara Üniversitesi, Sosyal Bilimler Enstitüsü, İstanbul.

Aysan, M. (2008). Uluslararası Finansal Raporlama Standartları ve Küresel Uyum. Muhasebe ve Finansman Dergisi, (40): 44-53.

Bağcı, H. (2002). Ulusal Muhasebe Standartları ve Uluslararası Standartlara Uyum. XVII. Türkiye Muhasebe Kongresi, İstanbul, 10- 12 Ekim, 21-30.

Bekçi, İ. \& Özdemir, O. (2006). Muhasebe Standartlarının Oluşum Süreci Ve Türkiye Finansal Raporlama Standartlarına Yönelik Muhasebe Meslek Mensuplarının Bakış Açıları Üzerine Bir Araştırma. Süleyman Demirel Üniversitesi İ̈BF Dergisi, (2): 143- 164.

Çelik, S. (2013). Muhasebe Meslek Mensuplarının Türkiye Muhasebe Ve Finansal Raporlama Standartlarına Bakış Açılarının Değerlendirilmesine İliş̧in Ampirik Bir Çalışma: Niğde Örneği. (Yayımlanmış Yüksek Lisans Tezi). Niğde Üniversitesi Sosyal Bilimler Enstitüsü İşletme Anabilim Dalı, Niğde.

Dinç, E. \& Erdoğan M. (2009). Türkiye Muhasebe Standartları Ve Muhasebe Meslek Mensuplarının Bilgi Düzeylerinin İncelenmesi. Muhasebe ve Finansman Dergisi, (43): 154-169.

Gezgin, S. (2005). Küreselleşmenin Medya ve Toplum Üzerindeki Etkileri. İstanbul Üniversitesi İletişim Fakültesi Dergisi, (21): 9-12.

Goyal, K. A. (2006). Impact of Globalization on Developing Countries (With Special Reference to India). International Research Journal of Finance and Economics, (5): 166-171.

Güneş, H. N. (2008). Tek Düzen Hesap Planının Muhasebe Standartlarına Uygunluğu SPK-TFRSUFRS’na Uygun Mali Tablo Düzenleme Uygulaması. İSMMMO Yayınları, Yayın no:102, İstanbul.

Güneş, R., Durmuş, A. F. \& Solak, B. (2012). Küreselleşmenin Muhasebe Uygulamalarına Etkisi. Akademik Yaklaşımlar Dergisi, 3(2): 57-66.

Güvemli, B. (2008). Uluslararası Muhasebe Standartları'nın Çeşitli Ülkelerin Muhasebe Kültürleri İle Etkileșimi Ve Türkiye Örneği. (Yayımlanmamış Doktora Tezi). Marmara Üniversitesi Sosyal Bilimler Enstitüsü İşletme Anabilim Dalı Muhasebe Finansman Bilim Dalı, İstanbul.

İçli, G. (2001). Küreselleşme ve Kültür. C. Ü. Sosyal Bilimler Dergisi, Aralık, 25(2): 163-172.

Kalmış, H. \& Dereköy, F. (2010). TMS-18’e Göre Hasılatın Muhasebeleştirilmesi ve Tekdüzen Muhasebe Sistemi ile Karşılaştırılması. Afyon Kocatepe Üniversitesi, İ.İ.B.F. Dergisi, 12(1): 123-145.

Karakaya, M. (2010). KOBİ'lerin Küresel Ekonomik İklime Uyumunda Uluslararası Finansal Raporlama Standartları. Muhasebe ve Vergi Uygulamaları Dergisi, 3(2): 1-25.

Kirac1, M. \& Köse, T. (2002). IASC, FASB ve TMUDESK' deki Muhasebe Standartları Oluşturma Süreci ve Uyumlaştırma. Osmangazi Üniversitesi Sosyal Bilimler Dergisi, 3(1): 47-70.

Kocamaz, H. (2012). Uluslararası Muhasebe Standartlarının Dünyada ve Türkiye'de Oluşum ve Gelişim Süreci. Kahramanmaraş Sütçü İmam Üniversitesi İktisadi ve İdari Bilimler Fakültesi Dergisi; 2(2): 105-120. 
Korkmaz, T., Temel, H. \& Birkan, E. (2007). Uluslararası Muhasebe Standartları ve KOBİ'lere Etkileri. Muhasebe ve Finansman Dergisi, (36): 96-105.

Kürkçü Dumanlı, D. (2013). Küreselleşme Kavramı ve Küreselleşmeye Yönelik Yaklaşımlar. The Turkish Online Journal of Design, Art and Communication TOJDAC, 3(2): 1-11.

Parlakkaya, R. (2004). Muhasebede Uluslararası Uyum Ve Avrupa Birliği Sürecinde Türkiye'de Muhasebe Uyumlaştırma Çalışmaları. SÜ İ̈BF Sosyal ve Ekonomik Araştırmalar Dergisi, 4(7): 119- 139 .

Şahin, D. \& Pazarçeviren, S. Y. (2007). TFRS (TMS 1, TMS 2, TMS 7, TMS 18, TMS 24, TMS 40) ve SPK Muhasebe Standartlarının IFRS ile Karşılaştırılması. Akademik İncelemeler Dergisi, 2(2): 129-146.

Tağraf, H. (2002). Küreselleşme Süreci ve Çokuluslu İşletmelerin Küreselleşme Sürecine Etkisi. C. Ü. İktisadi ve İdari Bilimler Dergisi, 3(2): 33-47.

Toraman, C. \& Bayramoğlu, F. M. (2006). Avrupa Birliği Uyum Sürecinin Muhasebe Uygulamalarına Etkisi. Mali Çözüm Dergisi (Özel Sayı), (76): 457-480.

Toroslu, V. (2014). Dönem Sonu Muhasebe İşlemleri, Seçkin Yayıncılık. Ankara.

Ürgüp Elden, S. (2016). Türkiye Muhasebe Standartlarının (TMS) Üretim Maliyeti Hesaplamasına Etkisi Ve Bir Uygulama. (Yayımlanmış Doktora Tezi). Cumhuriyet Üniversitesi Sosyal Bilimler Enstitüsü İşletme Ana Bilim Dalı Muhasebe Finansman Bilim Dalı. Sivas.

\section{EXTENDED ABSTRACT \\ A GENERAL OVERVIEW OF WORK IN ACCOUNTING APPLICATIONS DURING GLOBALIZATION}

\section{Background:}

Through long-term studies in the world of accounting; the main objective is to provide meaningful and realistic information in accounting applications and accounting reporting. Developed countries have worked for this purpose with the national accounting standards they put forward and the standards established by the boards or committees. Differences between the accounting standards of different countries make it difficult to compare the financial information obtained, cause difficulties in mergers and acquisitions of international companies and create a handicap in the capital market. Similar to many scientific systems, the accounting system changes in the axis of the developments in the world, or at least the world conditions impose this transformation. In line with the developments in the world, the accounting plans that form part of the accounting system should also be harmonized.

Standardization has been tried to be established in order to serve the common purpose with the effect of globalization movements in almost every subject. Standard expression; the degree of fitness for purpose. The similar use of events involving money and capital movements due to the fact that international trade has reached very important dimensions; In order to provide meaningful, reliable, truthfully comparable information, the information related to the business can be fulfilled the needs of the parties in the best way, preparation of financial reports on the accounting platform, preparation of international accounting standards in terms of theories and practices has resulted. With the high quality standards to be prepared, it is aimed to eliminate the accounting risk and to enable more trade, investment and growth. International accounting standards are based on the most transparent and accurate reflection of the assets and resources of the organization that the financial reports and tables represent. 


\section{Methodology:}

In the first part of the study, the process of globalization is given and in the second part, the effects of the accounting practices within the framework of international accounting standards are investigated.

\section{Research Purpose:}

This globalization process has created a single common market in the world. Additionally, globalization process, international goods and capital movements have increased at a rapid pace. This differentiation necessitated the transformation and transformation in accounting practices and led to the idea that the language of accounting should be applied in a common language instead of a different accounting language in the country. In this respect, the aim of the study is to examine accounting practices in the process of globalization. For this purpose, previous work on this subject will be examined within the framework of international accounting standards and a general evaluation will be made about accounting practices.

\section{Findings:}

With the globalization, in the last quarter century, a single language has been used within the enterprises in the world and accounting applications have progressed in parallel with the developments in commercial transactions. As a result of economic and technological developments, the globalization trend seen in the world has destroyed the geographical boundaries and provided the international distribution of many values. On the financial platform, globalization has led to the emergence of multinational companies, the establishment of international money and international audit firms, the development of capital markets, the increase of foreign capital participations and the accounting standards to exceed the national boundaries. It is possible to compare the financial statements of different countries and provide accurate and reliable information to international investors only by integrating them with international standards in accounting.

\section{Conclusions:}

Only national accounting practices are developing and changing on the axis of changes in economic and social order. For this reason, the existence of the special conditions of the whole country should not be ignored during the setting and integration of standards. Integrated studies should not consist solely of the translation of international accounting standards. As a result of the integrated effort, financial statements will be explained in a single language and accounting language around the world. Thus, the financial statements will have reached the norms and these norms are comparable, understandable, consolidated, reliable. In order to achieve national and international unity in accounting practices, accounting standards have been established. These studies have been carried out by more than one international organization. It is a common goal of these organizations to ensure that global accounting and financial reporting standards are established globally. IFAC and the IASC Foundation are the main institutions driving the global accounting climate, and IASB (International Accounting Standards Board) was established in 1973 to create a common accounting system for companies worldwide. İnternationally accepted accounting standards have been established under the name of the field and also Turkey Accounting standards (TAS) and Turkey Financial Reporting standards (IFRS) has emerged as accepted standards in Turkey. 